\title{
The Causality between Stock Market Development and Economic Growth: Econometric Evidence from Bangladesh
}

\author{
Abdullahil Mamun ${ }^{1,3,4}$, Mohammad Hasmat Ali $^{2}$, Nazamul Hoque ${ }^{3}$, Md Masrurul Mowla ${ }^{3}$ \& Shahanara Basher ${ }^{4}$ \\ ${ }^{1}$ The Scientific and Technological Research Council of Turkey (TUBITAK), Ankara, Turkey \\ ${ }^{2}$ Department of Finance, University of Chittagong, Chittagong, Bangladesh \\ ${ }^{3}$ Department of Business Administration, International Islamic University Chittagong, Chittagong, Bangladesh \\ ${ }^{4}$ Department of Economics, Cukurova University, Adana, Turkey \\ Correspondence: Nazamul Hoque, Department of Business Administration, International Islamic University \\ Chittagong, Chittagong, Bangladesh. Tel: 88-018-6060-0298. E-mail: nazam_iiuc@yahoo.com
}

Received: March 16, 2018

doi:10.5539/ijef.v10n5p212
Accepted: April 5, 2018

Online Published: April 20, 2018

URL: https://doi.org/10.5539/ijef.v10n5p212

\begin{abstract}
The growth performance of Bangladesh over the last one and a half decades along with the stock market development sparks the question of whether stock market development has a significant impact on economic growth of the economy. The study investigates the time series evidence of the influence of stock market development on growth of Bangladesh economy for the period 1993-2016 employing ARDL Bounds testing approach and finds stock market development has direct impact on economic growth both in the short-run as well as in the long run together with financial depth, interest rate spread and real effective exchange rate. Granger causality tests confirm a bidirectional causal relationship between stock market development and economic growth. However, the study fails to identify a system convergent to equilibrium in regard to stock market development along with other factors that has important economic implications. Persistent improvement in financial depth and fall in interest rate spread throughout the sample period with consistent performance of real effective exchange rate except some spikes in recent years raise the demand for playing the needed role by all concerned for confirming the stability of stock market and its development in order to validate the steady state of equilibrium in the long-run.
\end{abstract}

Keywords: stock market, market capitalization, economic growth, Bangladesh, Bounds test

\section{Introduction}

Being an integral part of financial system, stock market performs a pivotal role in mobilizing resources from capital abundant sector to the sector dearth of capital and thus contributes to the growth of an economy by allocating financial resources dexterously so as to mitigate investors' risk (Yartey \& Adjasi, 2007) and improving productivity through enhancing adeptness of financial intermediaries (Montiel, 1995; Caporale, 2004; Enisan \& Olufisayo, 2009; Levine \& Zervos, 1998). Stock market offers an opportunity to investors to collect capital at affordable cost. Full-fledged stock market reduces the risk of credit crunch substantially by offering ways of market-based financing instead of bank-based financing and thereby able to positively influence economic growth. It reduces the cost of acquiring information revealing information spontaneously through changes in prices. This helps undertake optimal investment decisions by companies and hence improve efficiency in resource allocation which results in higher rate of economic growth (Mamun et al., 2013). Stiglitz (1985) argues that the efficiency of the corporate sector is enhanced through a well-performing stock market that confirms effective monitoring of management and asserts corporate controls. However, growth deterring arguments of stock market are also available. Capital market increases liquidity through the reduction of uncertainty. By discouraging the desire for precautionary savings, higher liquidity in the stock market may exert adverse impact on the growth rate of an economy (Petros, 2012). Bhide (1994) warns about the potential problem associated with corporate governance that might have serious impacts on economic growth because of instant liquidity in the stock market that may damp down interest of the investors in maintaining long-term obligation with firms whose shares they own. Hence, the direction to which stock market development exerts impact on the growth of an economy needs empirical verification. 
The economy of Bangladesh has experienced a growth rate of around 6 percent over the last 12 years. Over the same period of time, the private sector of Bangladesh registers a rising contribution to its investment growth owing to the remarkable development of its stock market. Although the formal inauguration of stock exchanges in Bangladesh took place in 1954, no noticeable activities have been observed until the 1990s. Stock market development has been noticeable since the early 1990s with the initiatives of its liberalization. Total market capitalization reached to USD 43.5 billion in 2016 from USD 1.93 billion in 1995. The number of companies listed in the stock exchange is one of the key indicators of the development of capital market. The reason is that securities available in the marketplace and trading volume rise with the rise in the number of listed companies. The number of listed companies has been reached to 292 in 2016 with a growth rate of over 4.5 percent on average per annum from that of 192 in 1995. As the growth of Bangladesh economy is accompanied by a remarkable progress of its stock market, consequently it is rational to investigate whether stock market growth has any feature in predicting economic growth. The purpose of this paper is thus to evaluate the causal linkage between stock market development and real economic growth of Bangladesh empirically adopting an aggregate demand model with necessary modification.

The organization of the study is as follows: following introduction, the development of stock market in recent years is conferred in short in section two. A brief literature review of earlier studies is offered in section three. Section four works with data sources specification of the model, and methodology. Summarizing the empirical results in section five, the study ends with conclusions and policy recommendations.

\section{Recent Development in Capital Market}

Bangladesh has a capital market of more than 50 years old which has been playing a very significant role in the economy like other developed and developing countries. As like other South Asian capital markets, capital market of Bangladesh underwent liberalization in the early 1990s. In early liberalization periods, the market capitalization ratio as a measure of the size of the capital market was below 1.5 percent with less than 0.05 percent trade value as percent of GDP. The stock market of Bangladesh covered over 47 percent of Bangladesh's national output in 2010 which was the maximum in its history. There was an increasing trend of market capitalization ratio till 2010, which makes it evident that the size of value of capital stock has followed a rising trend. But following the stock market crush in 2010, the market capitalization ratio starts to decline. Despite the fall in market capitalization ratio, capital market still covers more than 25 percent of GDP of the economy which is significant and much higher than that of many other countries. In contrast, the turnover ratio is often used to measure the level of liquidity. The high turnover ratio is a sign of high level of liquidity. Illiquidity deters economic growth of an economy by hindering the capital-raising efforts of large domestic corporations (Bekaert \& Harvey, 1998). The turnover falls continuously after the stock market crush in 2010, revealing the crunch of liquidity in the capital market since the collapse. However, after a long period of ups and downs following the crunch owing to various policy shocks, the year 2016 was relatively stable as reflected by stock price indices which tempted people to participate in the capital market bring about higher turnover ratio and thus higher liquidity.

Table 1. Role of stock market in Bangladesh

\begin{tabular}{ccc}
\hline Year & Market capitalization Ratio & Turnover Ratio \\
\hline 1993 & 1.40 & 3.2 \\
2000 & 4.11 & 42.7 \\
2010 & 47.75 & 11.6 \\
2011 & 37.54 & 4.77 \\
2012 & 29.92 & 2.01 \\
2013 & 29.01 & 1.90 \\
2014 & 31.87 & 1.96 \\
2015 & 27.38 & 1.57 \\
2016 & 25.87 & 3.76 \\
\hline
\end{tabular}

Source: World Development Indicators, World Bank, 2016.

\section{Literature Review}

A good series of studies have been conducted in order to research the relationship between stock market development and economic growth. While many of the studies report that stock market development supports economic growth, studies with counter and weak evidences are also considerable.

Coşkun et al. (2017) examine the relations between the development level of capital market sub-components and 
economic growth over the period 2006-2016 using quarterly data in Turkey employing ARDL approach, Markov Switching Regression and Kalman Filter models, and discover a long-run cointegrating relationship between development of capital market and economic growth and also a unidirectional causality running from capital market development to economic growth. Drawing different measures of stock market development from across-section of 42 countries between 1976 and 1993, Levine and Zervos (1998) find that the primary level of liquidity in the stock market and bank credits are directly and significantly correlated with future economic growth. Holmstrom and Tirole (1993), and Bencivenga et al. (1995) in their study also prove that liquidity in the stock market expedites long-run growth. Beck and Levine (2004), relying on recent generalized-method-of moments techniques developed for dynamic panels, identifies the positive influence of stock markets and banks on economic growth for the period 1976-1998 for a group of countries. Employing principal component analysis in order to develop an acceptable measures of financial development with the objective to examine the nexus between financial development and growth for data from 146 economies over the years 1991-2011, Seven and Yetkiner (2016) find that development in the stock market and economic growth are positively and significantly related in middle- and high-income countries. Cross-country growth regressions of Levine and Zervos (1996) assert a positive and robust association between the predetermined component of stock market development and long-run economic growth. In a study examining the long run association and short-run causal relationship between stock market development and economic growth for seven countries in sub-Saharan Africa, Enisan and Olufisayo (2009) employ the autoregressive distributed lag (ARDL) bounds test and reach to the conclusion that growth of stock market support long-run economic growth significantly and positively. A similar result is found by Adjasi and Biekpe (2006) conducted in a dynamic panel data modeling setting for 14 African countries. Nordin and Nordin (2016) examine the influence of stock market on economic growth employing Johansen cointegration approach and find a positive significant impact of stock market on the Malaysian economy. In a study on Pakistan, Shahbaz et al. (2008) investigate if there is an association between stock market development and economic growth for the period 1971-2006 using ARDL approach and find that there exists a very strong link between stock market development and economic growth. A study performed by Van Nieuwerburgh et al. (2006) shows strong evidence that progress in stock market leads to economic growth in Belgium, particularly for the period 1873-1935. Another study by Ahmed and Ansari (1998) investigate financial sector development and economic growth relationship for India, Pakistan, and Sri Lanka over the period 1973-1991. Results of the causality analysis suggest that economic growth is caused by financial sector development in the Granger sense for these countries.

As mentioned, empirical studies revealing negative and mixed results concerning the association between the development of stock market and growth are also remarkable. Based on data from 49 developing economies through 1980 and 1991, Harris (1997) identifies a weak effect of progress in stock markets on growth in developing countries. Samargandi et al. (2014) performs a study on Saudi Arabia with an aim to investigate the effect of the development of financial sector on economic growth with reference to oil-rich economies using Autoregressive Distributed Lag (ARDL) bound test technique allowing the impact of financial development to vary across the oil and non-oil sectors and find financial development has an impact positive to the Saudi non-oil sector growth only, however, the impact on total GDP growth is trivial. Barajas et al. (2013) draw data from 150 countries for the period 1975-2005. Their dynamic panel estimation results suggest that the beneficial effect of financial deepening on growth is smaller in oil-abundant countries (the Middle East and North Africa) and low-income countries.

Employing time series econometrics and data from five developed economies, Arestis et al. (2001) look at the association between development of stock market and economic growth, controlling the volatility effects of the banking system and stock market they do not find strong evidence to argue that progress in stock markets promote growth of an economy. In a study on eleven MENA region countries, Naceur and Ghazouani (2007) find that there exists no significant relationship between the development of financial sector and growth. However, Boubakari and Jin (2010) identify a positive association between stock market and economic growth depending on their time series evidence collected from 5 Euronext countries over 1995-2008 based on Granger causality test which is particularly true for economies with highly liquid and active stock market. However, it rejects the causality linkage for the countries having small and less liquid stock market. In addition, a study by Wang and Ajit (2013) on China reveals that stock market impacts economic growth adversely during 1996-2011. Thornton (1995) studies the role of financial deepening in economic growth using Granger-causality tests on 22 developing economies from Latin America, Caribbean and Asia, and notices that financial deepening does not produce much difference to economic growth for many instances.

Tang et al. (2007), while investigating the influence of capital market on economic growth in 12 Asian 
economies over the period 1980-2004, find that capital market has a long-run impact on economic growth only in four of the twelve economies, namely Philippines, Singapore, Taiwan and China. Results derived from the Granger causality tests indicate a bidirectional causality relationship between stock markets and economic growth merely in the case of China, Indonesia, Malaysia, Hong Kong and Thailand. Nevertheless, the causal effect is unidirectional running from stock markets to economic growth in the short-run for the case of Japan and Korea and from economic growth to stock markets in the short-run for India and Singapore. However, the causality is absent among the variables in the case of Sri Lanka alone.

Very few of the studies on South Asian region based on panel data consider Bangladesh in their sample and results are not also conclusive. Haque and Hossain (2011) empirically investigate the impact of progress in stock market on economic growth for four SAARC countries namely Bangladesh, Pakistan, and Sri Lanka India, for the period 1980-2008 and find that the sizes of stock market, activity and liquidity have no impact on real economic activity in this area. The role of the development of stock market in economic growth for four Asian countries namely China, India, Bangladesh and Singapore drawing annual time series data from 1991 to2012 with the help of ARDL bound testing approach, Azam et al. (2016) find a long-term cointegration between economic growth and progress of stock market. Ullah and Wizarat (2016) study the contribution of stock market development towards economic growth in case of four South Asian economies, India, Bangladesh, Pakistan and Sri Lanka for the period 1990 to 2011 using panel data based on an index developed by combining the components of stock market development using Principal Component Analysis. Their results reveal that development in stock market results in economic growth in the long run as well as in the short run. However, this is the first time series study to investigate the impact of stock market development on economic growth of Bangladesh.

\section{Data and Methodology}

\subsection{Data Sources}

The paper considers the ratio of stock market capitalization as a measure of stock market development and studies the causal relationship among GDP, stock market development, financial depth, interest rate spread and real effective exchange rate. It relies on yearly time series data for the period 1993-2016. Sources and necessary explanations of the variables are summarized in table 2. Real values of variables relevant for our study are taken considering 2010 as the base year.

Table 2. Variables, descriptions, and sources

\begin{tabular}{ccc}
\hline Variable & Explanation & Source \\
\hline GDP & Gross Domestic Product & World Development \\
SMD & Stock market capitalization ratio: the value of listed shares divided by GDP & Indicators, World Bank, 2016 \\
FD & Financial depth: Broad money divided by GDP & \\
IRS & Interest Rate Spread: the difference between lending and deposit rate, $\%$ & Bruegel Datasets, 2016 \\
REER & Real Effective Exchange Rate &
\end{tabular}

The Augmented-Dickey-Fuller (ADF) and Phillips-Perron (PP) Unit Root Tests are applied to identify the order of integration of the variables. Table 3 summarizes the test results. According to the unit root test results, all the variables are found to be stationary at first difference for both trend and trend with intercept processes and therefore all the variables are integrated of order 1, that is, they all are I(1) processes. Hence, regression will be spurious at their levels. Therefore, they must pass the cointegration test not to lose any long-term information.

Table 3. Augmented-Dickey-Fuller (ADF) and Phillips-Perron (PP) unit root test

\begin{tabular}{|c|c|c|c|c|c|c|}
\hline \multirow[t]{2}{*}{ Variables } & \multirow[t]{2}{*}{ Test in } & \multirow[t]{2}{*}{ Includes } & \multicolumn{2}{|c|}{$\mathrm{ADF}$} & \multicolumn{2}{|c|}{$\mathrm{PP}$} \\
\hline & & & & & t-statistic & p-value \\
\hline \multirow{4}{*}{$\operatorname{lnGDP}$} & \multirow{2}{*}{ Level } & Intercept & 2.791 & 1.0000 & 5.194787 & 1.0000 \\
\hline & & Trend, Intercept & -1.226 & 0.8781 & -0.869143 & 0.9428 \\
\hline & \multirow{2}{*}{ First Difference } & Intercept & -3.801 & $0.0071^{*}$ & -3.953 & $0.0047 *$ \\
\hline & & Trend, Intercept & -6.313 & $0.0000^{*}$ & -6.179 & $0.0000 *$ \\
\hline \multirow{4}{*}{$\operatorname{lnSMD}$} & \multirow{2}{*}{ Level } & Intercept & -2.060 & 0.2612 & -2.060315 & 0.2612 \\
\hline & & Trend, Intercept & -3.627 & 0.0495 & -3.645360 & 0.0478 \\
\hline & \multirow{2}{*}{ First Difference } & Intercept & -5.912 & $0.0001^{*}$ & -8.257843 & $0.0000 *$ \\
\hline & & Trend, Intercept & -5.785 & $0.0006^{*}$ & -7.812665 & $0.0000 *$ \\
\hline
\end{tabular}




\begin{tabular}{|c|c|c|c|c|c|c|}
\hline \multirow{4}{*}{$\ln I R S$} & \multirow{2}{*}{ Level } & Intercept & -2.018 & 0.2777 & -2.017593 & 0.2777 \\
\hline & & Trend, Intercept & -2.191 & 0.4719 & -2.254552 & 0.4400 \\
\hline & \multirow{2}{*}{ First Difference } & Intercept & -4.824 & $0.0009^{*}$ & -4.823872 & $0.0009 *$ \\
\hline & & Trend, Intercept & -4.784 & $0.0049^{*}$ & -4.784064 & $0.0049^{*}$ \\
\hline \multirow{4}{*}{ REER } & \multirow{2}{*}{ Level } & Intercept & -0.638 & 0.8425 & 0.361201 & 0.9764 \\
\hline & & Trend, Intercept & 1.391 & 0.9999 & 0.632706 & 0.9990 \\
\hline & \multirow{2}{*}{ First Difference } & Intercept & -4.706 & $0.0007 *$ & -5.564 & $0.0001 *$ \\
\hline & & Trend, Intercept & -4.445 & $0.0070^{*}$ & -5.066 & $0.0016^{*}$ \\
\hline
\end{tabular}

Note. Figures in brackets show the lag length.

* Significant at $5 \%$ level; ** Significant at $10 \%$ level.

\subsection{Model and Methodology}

Among the alternative approaches such as Engle-Granger (1987) procedure, Johansen's (1996) cointegration approach and ARDL Bounds testing approach to study the long-run cointegrating relationships among time series variables, the study benefits from the last since it is appropriate for small sample size as the case of ours to avoid small sample bias does not matter whether the series under consideration are $\mathrm{I}(0), \mathrm{I}(1)$ or mutually cointegrated (Pesaran et al., 2001). Rest of the approaches requires relatively large sample and variables of the same order of integration. Based on an extensive literature survey, the study initially considers the explanatory variables stock market capitalization ratio as a measure of stock market development, turnover ratio, financial depth, inflation rate, interest rate spreads and real exchange rate that have been used in many studies so as to formulate a general model. The initial specification of the general model is left unaltered along with other specifications allowing different combinations of explanatory variables in estimating an Error Correction Model (ECM) applying cointegration technique. Statistically insignificant or uncointegrated specifications are then removed and finally, the following model is devised for Bangladesh:

$$
G D P=f(S M D, I R S, R E E R)
$$

The long-run cointegrating regression model and the ARDL scheme following the conventional ECM for cointegrating variables can be given as-

$$
\begin{gathered}
\operatorname{lnGDP}_{t}=\alpha_{0}+\alpha_{1} \operatorname{lnSMD}_{t}+\alpha_{2} \ln F D_{t}+\alpha_{3} I R S_{t}+\alpha_{4} R E E R_{t}+u_{t} \\
\Delta \operatorname{lnGDP_{t}}=\beta_{0}+\Sigma \beta_{i} \Delta \ln G D P_{t-i}+\Sigma \gamma_{j} \Delta \operatorname{lnSM} D_{t-j}+\Sigma \delta_{k} \Delta \ln F D_{t-k}+\Sigma \eta_{l} \Delta I R S_{t-l}+\Sigma \eta_{l} \Delta R E E R_{t-l}+\theta E C T_{t-1}+e_{t}
\end{gathered}
$$

Here, ECT stands for "error-correction term", which is the OLS residuals series found for long-run cointegrating regression model (1). The ratio of Stock market capitalization to GDP can be used as a measure of market development. Market capitalization, financial depth and real effective exchange rate potentially have positive impacts on economic growth while higher interest rate spread discourages potential savers and is a barrier for potential investors and thereby hinders economic growth. Thus, the expected signs for the long run coefficients are $\alpha_{1}>0, \alpha_{2}>0, \alpha_{3}<0, \alpha_{4}>0$.

\section{Empirical Results}

The Bounds test result is shown in Table 4. Clearly, the value of F-statistics lies entirely above the lower and upper bond values and hence test result rejects the null hypothesis 'no long-run relationships exist' for growth equation, therefore a long-run cointegrating relationship among the variables exists.

Table 4. Bound test for examining the existence of cointegrating relation

\begin{tabular}{ccccc}
\hline \multirow{2}{*}{ Dependent Variable } & F-statistics & \multicolumn{3}{c}{ Critical Value Bounds* } \\
\cline { 3 - 5 } & & Significance & Lower Bound & Upper Bound \\
\hline & & $10 \%$ & 2.2 & 3.09 \\
GDP & 6.3197 & $5 \%$ & 2.56 & 3.49 \\
& & $2.5 \%$ & 2.88 & 3.87 \\
\hline
\end{tabular}

Note. * Pesaran Critical Values.

As there prevails a long-run cointegrating relationship among the variables, we are now in the position to estimate short-run dynamics and the adjustment toward the long-run equilibrium. The appropriate model to estimate long-run cointegrating relationship is $\operatorname{ARDL}(2,2,2,1,1)$ based on Akaike Information Criteria (figure 1). The problem of serial correlation is found to be absent for the stable model (figure 2), which is the precondition 
for the validity of Bounds test results.

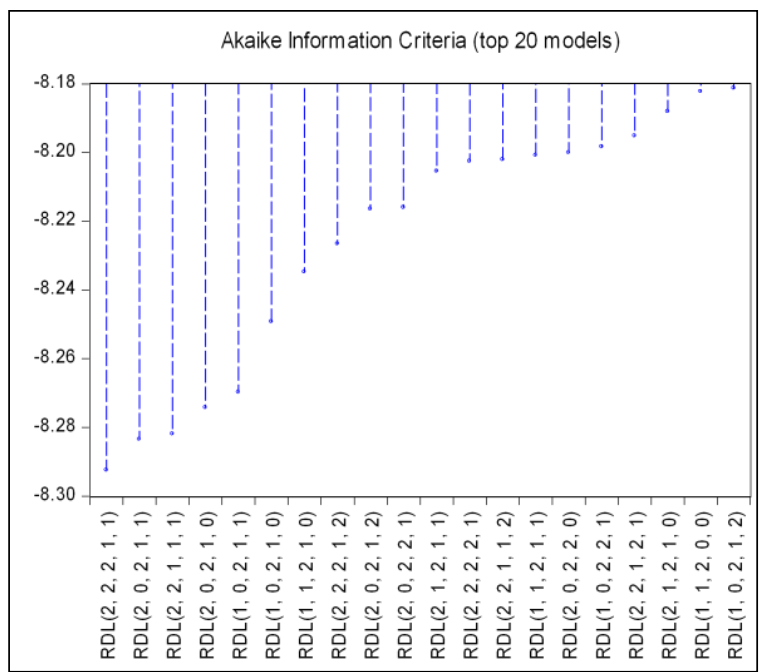

Figure 1. Model selection summary

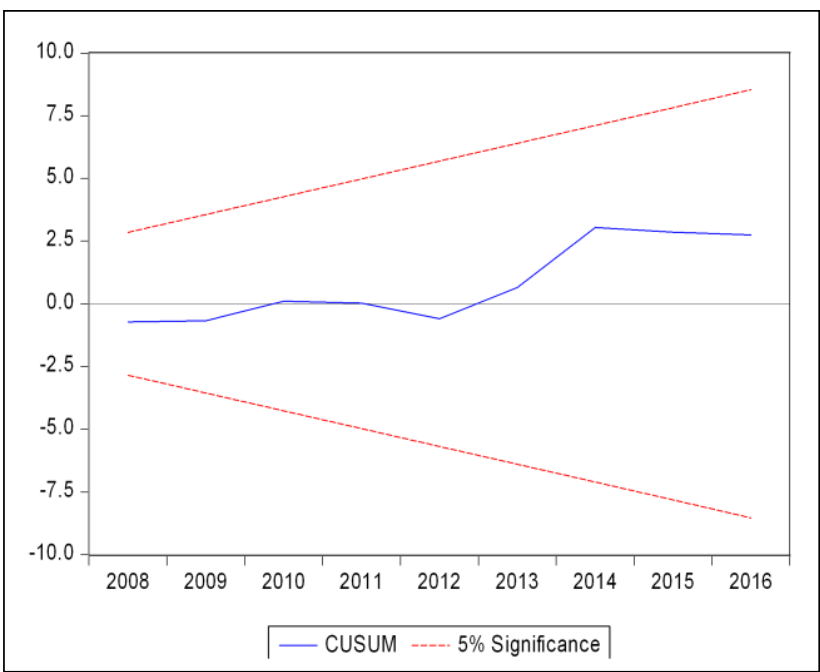

Figure 2. Stability diagnosis

Estimated long-run model is shown below. It is evident that all the long run coefficients maintain expected signs and appear to be statistically significant at 5 percent level. Figures in brackets show t-ratios. Results exhibit that stock market development, financial depth and undervaluation of real effective exchange rate have a positive impact on economic growth of Bangladesh, while interest rate spread deters economic growth.

$$
\operatorname{lnGDP_{t}}=22.223+0.136 \operatorname{lnSMC}_{t}+0.356 \operatorname{lnF} D_{t}-0.111 I R S_{t}+0.279 \operatorname{lnREER}_{t}+u_{t}
$$

$$
\text { (43.938) (5.222) (3.235) (-3.127) (2.637) }
$$

The dynamic short-run ECM for ARDL $(2,2,2,1,1)$ scheme is shown in Table 5. The sigh and magnitude of the coefficient of ECT determine the stability of the model in the long-run that needs to be ranged from 0 and 2 with a negative sign and highly significant to ensures the presence of long-run equilibrium relationship among economic growth, stock market capitalization, financial depth, interest rate spread and real effective exchange rate. The study finds a highly significant coefficient of ECT but positive (0.125), meaning that long-run equilibrium relationship between regressors (SMD, FD, IRS, REER) and regress and (GDP) does not exist.

Table 5. Error-correction Estimate for ARDL Model

\begin{tabular}{ccccc}
\hline Variable & Coefficient & Std. Error & t-Statistic & Prob. \\
\hline D(lnGDP(-1)) & -0.412712 & 0.188512 & -2.189308 & 0.0563 \\
D(lnSMD) & -0.012290 & 0.001375 & -8.937253 & 0.0000 \\
D(lnSMD(-1)) & 0.002017 & 0.000844 & 2.390925 & 0.0405 \\
D(lnFD) & -0.095745 & 0.012584 & -7.608215 & 0.0000 \\
D(lnFD(-1)) & 0.038078 & 0.016957 & 2.245598 & 0.0514 \\
D(IRS $)$ & 0.002568 & 0.002607 & 0.985048 & 0.3503 \\
D(REER) & -0.073871 & 0.015496 & -4.767136 & 0.0010 \\
ECT(-1) & 0.124943 & 0.016268 & 7.680067 & 0.0000 \\
\hline
\end{tabular}

Short-term Granger causality test is employed on ECM so as to identify the shout-run causal relationship among the variables. The Wald-statistics of short-run test for causality are summarized in Table 6. Wald test statistics indicate that the null hypothesis of absence of causality from stock market development to GDP is rejected at 1 percent level of significance. Again, a causal relationship that goes from GDP to stock market development is also evident as the null hypothesis 'GDP does not cause SMD' is not accepted at 1 percent significance level. Hence, there prevails a bidirectional causal nexus between stock market development and economic growth. Furthermore, financial depth and interest rate spread can cause GDP as the null hypothesis 'financial depth and interest rate spread do not cause GDP' is rejected at 1 percent level of significance, while the null hypothesis of the absence of causal relationship from real effective exchange rate to GDP is rejected at 5 percent level of 
significance. Thus, economic growth of Bangladesh is caused by stock market development together with financial depth, interest rate spread and real effective exchange rate in the short run.

Table 6. Wald test results

\begin{tabular}{ccc}
\hline Null Hypothesis & Chi-square & p-value \\
\hline SMD-does-not-cause-GDP & $41.269^{*}$ & 0.0000 \\
GDP-does-not-cause-SMD & $58.213^{*}$ & 0.0000 \\
FD-does-not-cause-GDP & $19.875^{*}$ & 0.0002 \\
IRS-does-not-cause-GDP & $11.257^{*}$ & 0.0036 \\
REER-does-not-cause-GDP & $8.621 * *$ & 0.0134 \\
\hline
\end{tabular}

Note. $*$ Significant at $1 \%$ level; ** Significant at $5 \%$ level.

\section{Conclusions and Policy Recommendation}

The growth performance of Bangladesh over the last one and a half decades along with the remarkable progress of stock market sparks the question of whether stock market development has a significant impact on economic growth of the economy. Despite the study finds a positive impact of stock market development over economic growth both in the short run and in the long run, the long run stability of the system is not found to be evident, that is, the system does not have a tendency to come back to its equilibrium in the long run that has important economic implication. The stock market of Bangladesh experienced two major collapses in a fourteen-year interval: one was in 1996, and the other was in 2010. The first burst was due to weak institutions structure and inadequate governance following which affected investors stand back from the capital market for the subsequent years. However, it also helped operational developments of stock market. Introduction of electronic trading in 1998, the establishment Central Depository Bangladesh Ltd (CDBL) in 2000 and the integration of the Central Depository System (CDS) in 2004 improved regulatory environment of the stock market. Following the relative inactivity for an extended period, the stock market began to pull through in April 2004. But the investments of foreign institutional investors and banks pave the way for appreciation of the market, by the end of 2010, stock market capitalization of Bangladesh exceeds 47 percent of its GDP, which was more than 60 times from that of 2000. But the bubble was momentary as the market collapsed in December 2010. As like the first burst in 1996, there was some significant development in stock market regulation following the second burst, namely The Exchange Demutualization Act 2013 was passed, surveillance software was installed so as to confirm transparency and accountability, Demutualization Act, the Banking Control Act (BCA) and Financial Reporting Act had been approved by the parliament. To sum up, the stock market of Bangladesh witnesses lots of ups and downs throughout the sample period. Consequently, despite the high market capitalization as a percent of GDP, a measure of stock market development, the economy fails to register a system convergent to equilibrium in regard to stock market development. Over the same period of time, persistent improvement in financial depth and fall in interest rate spread have been acknowledged while real effective exchange rate is found to be consistent except some spikes in recent years. Hence, given the short-run as well as the long-run significance of stock market in economic growth as evident from the study, all concerned should play the roles needed for confirming the stability of stock market and its development to validate the steady state of equilibrium in the long-run.

\section{References}

Adjasi, C. K., \& Biekpe, N. B. (2006). Stock market development and economic growth: The case of selected $\begin{array}{lllll}\text { African } & \text { countries. African Development }\end{array}$ https://doi.org/10.1111/j.1467-8268.2006.00136.x

Ahmed, S. M., \& Ansari, M. I. (1998). Financial sector development and economic growth: The South-Asian experience. Journal of Asian Economics, 9(3), 503-517. https://doi.org/10.1016/S1049-0078(99)80100-6

Arestis, P., Demetriades, P. O., \& Luintel, K. B. (2001). Financial development and economic growth: the role of stock markets. Journal of Money, Credit and Banking, 16-41. https://doi.org/10.2307/2673870.

Azam, M., Haseeb, M., Samsi, A. B., \& Raji, J. O. (2016). Stock Market Development and Economic Growth: Evidences from Asia-4 Countries. International Journal of Economics and Financial Issues, 6(3).

Barajas, M. A., Chami, M. R., \& Yousefi, M. R. (2013). The finance and growth nexus re-examined: Do all countries benefit equally? (No. 13-130). International Monetary Fund. https://doi.org/10.5089/9781484372104.001

Beck, T., \& Levine, R. (2004). Stock markets, banks, and growth: panel evidence. J. Bank. Financ., 28(3), 
423-442. https://doi.org/10.1016/S0378-4266(02)00408-9

Bekaert, G., \& Harvey, C. R. (1998). Capital markets: An engine for economic growth. The Brown Journal of World Affairs, 5(1), 33-53. https://doi.org/10.2307/24589952

Bencivenga, V. R., Smith, B. D., \& Starr, R. M. (1995). Transaction Costs, Technical Choice and Endogenous Growth. Journal of Economic Theory, 67(1), 53-177. https://doi.org/10.1006/jeth.1995.1069

Bhide, A. (1993). The hidden costs of stock market liquidity. Journal of Financial Economics, 34(1), 31-51. https://doi.org/10.1016/0304-405X(93)90039-E

Boubakari, A., \& Jin, D. (2010). The role of stock market development in economic growth: evidence from some Euronext countries. Int. J. Financ. Res., 1(1), 14-20. https://doi.org/10.5430/ijfr.v1n1p14

Caporale, G. M., Howells, P. G., \& Soliman, A. M. (2004). Stock market development and economic growth: The causal linkage. Journal of Economic Development, 29(1), 33-50. Retrived from http://www.jed.or.kr/full-text/29-1/02_J665_.PDF

Coşkun, Y., Seven, Ü., Ertuğrul, H. M., \& Ulussever, T. (2017). Capital market and economic growth nexus: Evidence from Turkey. Central Bank Review, 17(1), 19-29. https://doi.org/10.1016/j.cbrev.2017.02.003

Enisan, A. A., \& Olufisayo, A. O. (2009). Stock market development and economic growth: Evidence from seven sub-Sahara African countries. Journal of Economics and Business, 61(2), 162-171. https://doi.org/10.1016/j.jeconbus.2008.05.001

Haque, M. E., \& Hossain, M. K. (2011). Impact of stock market development on economic growth: Evidence from SAARC countries. Eastern University Journal, 3(3), 1-13. Retrived from http://dspace.easternuni.edu.bd:8080/xmlui/handle/12345/49

Harris, R. D. (1997). Stock markets and development: A re-assessment. European Economic Review, 4l(1), 139-146. https://doi.org/10.1016/S0014-2921(96)00021-9

Holmstrom, B., \& Tirole, J. (1993). Market Liquidity and Performance Monitoring. Journal of Political Economy, 101(4), 678-709. https://doi.org/10.1086/261893

Levine, R., \& Zervos, S. (1996). Stock market development and long-run growth. The World Bank Economic Review, 10(2), 323-339. https://doi.org/10.1093/wber/10.2.323

Levine, R., \& Zervos, S. (1998). Stock markets, banks, and economic growth. American Economic Review, 88(3), 537-558. https://doi.org/10.1016/j.ribaf.2006.05.002

Mamun, A., Aziz, M. S. I., Uddin, M. R., \& Hoque, N. (2013). The Impact of Investors' Information Search Behavior on Bangladesh Stock Markets. Middle-East Journal of Scientific Research, 18(11), 1625-1631. https://doi.org/10.5829/idosi.mejsr.2013.18.11.12463

Montiel, P. J. (1995). Financial Policies and Economic Growth: Theory, evidence and country specific experience from Sub-Saharan Africa. African Economic Research Consortium, Nairobi, KE. Retrived from https://idl-bnc-idrc.dspacedirect.org/bitstream/handle/10625/13595/102422.pdf?sequence=1

Naceur, S. B., \& Ghazouani, S. (2007). Stock markets, banks, and economic growth: Empirical evidence from the MENA region. Research in International Business and Finance, 21(2), 297-315. https://doi.org/10.1016/j.ribaf.2006.05.002

Nordin, S., \& Nordin, N. (2016). The impact of capital market on economic growth: A Malaysian outlook. International Journal of Economics and Financial Issues, 6(7S).

Pesaran, M. H., Shin, Y., \& Smith, R. J. (2001). Bounds testing approaches to the analysis of level relationships. Journal of applied econometrics, 16(3), 289-326. https://doi.org/10.1002/jae.616

Petros, J. (2012). The effect of the stock exchange on economic growth: A case of the Zimbabwe stock exchange. Research in Business and Economics Journal, 6, 1.

Samargandi, N., Fidrmuc, J., \& Ghosh, S. (2014). Financial development and economic growth in an oil-rich economy: The case of Saudi Arabia. Economic Modelling, 43, 267-278. https://doi.org/10.1016/j.econmod.2014.07.042

Seven, Ü., \& Yetkiner, H. (2016). Financial intermediation and economic growth: Does income matter? Economic Systems, 40(1), 39-58. https://doi.org/10.1016/j.ecosys.2015.09.004

Shahbaz, M., Ahmed, N., \& Ali, L. (2008). Stock market development and economic growth: ARDL causality in 
Pakistan. International Research Journal of Finance and Economics, 14(1), 182-195. Retrived from http://citeseerx.ist.psu.edu/viewdoc/download?doi=10.1.1.453.2757\&rep=rep1\&type=pdf

Stiglitz, J. E. (1985). Credit Markets and the Control of Capital. Journal of Money, Credit and Banking, 7(2), 133-152. http://dx.doi.org/10.2307/1992329

Tang, H. P., Habibullah, M. S., \& Puah, C. H. (2007). Stock market and economic growth in selected Asian countries. Journal of Economics, Finance and Administrative Sciences, (7), 43-52. Retrieved from https://mpra.ub.uni-muenchen.de/id/eprint/37649

Thornton, J. (1996). Financial deepening and economic growth in developing economics. Applied Economics Letters, 3(4), 243-246. https://doi.org/10.1080/758520872

Ullah, Z., \& Wizarat, S. (2016). Long term relationship between stock market development and economic growth in south asia: Panel data \& ardl model estimations. Pakistan Business Review, 18(3), 541-557. Retrieved from http://www.journals.iobmresearch.com/index.php/PBR/article/download/944/194

Van Nieuwerburgh, S., Buelens, F., \& Cuyvers, L. (2006). Stock market development and economic growth in Belgium. Explorations in Economic History, 43(1), 13-38. https://doi.org/10.1016/j.eeh.2005.06.002

Wang, B., \& Ajit, D. (2013). Stock market and economic growth in China. Economics Bulletin, 33(1), 95-103. Retrieved from https://ecomod.net/system/files/StockMarket-wang-ajit-ECOMOD.pdf

World Bank. (2016). World Development Indictors.

Yartey, C. A., \& Adjasi, C. K. (2007). Stock market development in Sub-Saharan Africa: Critical issues and challenges. IMF Working Paper No. 7-209, International Monetary Fund.

\section{Copyrights}

Copyright for this article is retained by the author(s), with first publication rights granted to the journal.

This is an open-access article distributed under the terms and conditions of the Creative Commons Attribution license (http://creativecommons.org/licenses/by/4.0/). 